\title{
Stimulating Higher-Order Thinking skills (HOTs) with the Module on Metabolism Topic at the Senior High School in Surakarta
}

\author{
${ }^{1 s t}$ Betty Novia Pramesti \\ Student of Post Graduate Program at \\ Sebelas Maret University \\ Surakarta, Indonesia \\ noviapramesti@gmail.com
}

\author{
2nd Sajidan \\ Department of Science Education, \\ Master Degree Program of Sebelas \\ Maret University \\ Surakarta, Indonesia \\ sajidan@fkip.uns.ac.id
}

\author{
${ }^{3 r d}$ Sri Dwiastuti \\ Department of Science Education, \\ Master Degree Program of Sebelas \\ Maret University \\ Surakarta, Indonesia \\ astuti@uns.ac.id
}

\begin{abstract}
Disruptive era is an era with the rapid progress in various fields. Every individual is required to possess qualified skills to keep up with the rapid progress. One of the skills that must be possessed is Higher-Order Thinking Skills (HOTs). The purpose of this research was to find out how to stimulate students' HOTs using a module. The module used in this study was the module developed based on the syntaxes of Stimulating Higher-Order Thinking Skills (Stim-HOTs) model on cell metabolism. This research was quasi-experimental research of non-equivalent control-group design in one of the senior high schools in Surakarta. The sample consisted of 66 students divided into two classes, the control class, and the module class. The instruments used in the data collection were the pre-test and post-test of cell-metabolism topic. The results showed that HOTs stimulation could be performed using the Stim-HOTs-based module.
\end{abstract}

\section{Keywords-Higher-Order Thinking skill (HOTs), module}

\section{INTRODUCTION}

Disruption is a fundamental change that is currently taking place in various fields including education. Various breakthroughs and findings in the forms of invention and innovation in science and technology are discovered. If they are applied to everyday life on a continuous basis, they will certainly impact on fundamental changes. Indonesia, as a part of the world, must be able to adapt to the current changes in various parts of the world especially in the developed countries that affect much of human life [1]. The disruptive era of the $21^{\text {st }}$ century requires students to adapt to changes. Competencies or skills expected by the students include: (a) life and career skills, i.e. the ability to synthesize information and work as a team to manage it broadly and complexly and responsibly to the society and the environment; (b) skills in information, media, and technology; and (c) critical learning and innovation skills [2].

According to the $21^{\text {st }}$ Century Partnership Learning Framework [3], the competencies or skills that must be possessed by $21^{\text {st }}$ century Human Resources among other things are critical-thinking and problem-solving skills, communication and collaboration skills, creativity and innovation skills, information and communication technology literacy, contextual learning skills, and information and literacy media skills. The summary of the $21^{\text {st }}$-century thinking-competence map in Indonesia is often known as $4 \mathrm{C}$, namely critical thinking and problem solving, creativity, communication skills, and ability to work collaboratively. Changes in the world of education are needed to meet these demands and challenges, more specifically the change in action from simple action toward comprehensive one and teaching transition, i.e., traditional and non-algorithmic teaching dominated by Low-Order Thinking skills (LOTs) to the learning which empowers Higher-Order Thinking skills (HOTs) [4].

Resnick [5] asserted that Higher-Order Thinking skills (HOTs) is a complex process of thinking in describing materials, building representations, analyzing, and building relationships by involving the most basic mental activities and making conclusions. Higher-Order Thinking skills (HOTs) are the basis of various higher-order mental processes according to the levels in Bloom's taxonomy [6]. According to Bloom, knowledge, understanding, and creation are classified as lower-order thinking skills (C1, C2, and $\mathrm{C} 3$ ) that form the basis of students' thinking processes, while analysis, synthesis, and evaluation (C4, C5, and C6) are classified as Higher-Order Thinking skills (HOTs) which are the continuation of the thinking process at a higher level [7]. Brookhart [8] explained that Higher-Order Thinking skills (HOTs) could be divided into three categories: (1) HOTs as the transfer of knowledge; (2) HOTs as critical thinking; and (3) HOTs as problem-solving.

Higher-Order Thinking skills (HOTs) as a transfer is generally based on the Taxonomy of Educational Objectives, Handbook I: Cognitive Domain [9] consisting of analysis, synthesis, and evaluation. Anderson and Krathwohl [10] revised Bloom's taxonomy by classifying higher-order thinking skills into analysis, evaluation, and creation. The revised taxonomy of Anderson and Krathwohl also has a more complex set of cognitive processes by adding dimensions of factual, conceptual, procedural and metacognitive knowledge.

Thinking skill is the most basic ability of any individual. The main task of educators is to provide space and facilities for students to become effective and efficient thinkers through the right-thinking process. Things that can be done by educators include providing appropriate teaching 
strategies, methods, and materials to facilitate the growth of higher-order thinking skills [11]. According to some researches, students' higher-order thinking skills can be stimulated by the development of learning models as well as the development of teaching materials, one of which is a module. The research found to be associated with the solution for improving higher-order thinking skills is the development of model-based modules.

Pratiwi, et al [12] in their research on the development of the biological module based on hybrid learning model explained that the module could help students learn independently and more responsibly with the results of their thinking in the learning process. This statement is supported by [13] which explain that students can proceed to follow the flow or syntaxes of the learning model contained in the module and obtain the concept of the material being studied well. Stimulating Higher-Order Thinking Skills (Stim-HOTs) is the model designed to encourage students' freedom of thought combined with collaborative, communication, and ICT skills [11]. The Stim-HOTs model is designed according to the $21^{\text {st }}$-century thinking competence framework so it has the potential to improve the level of thinking skills from LOTs to HOTs. This is of course in line with the expectations of the government and educators particularly in the effort of stimulating students' HOTs.

Cell metabolism topic becomes the special topic chosen in this research by the results of the analysis of the absorptive capacity of the National Examination on the topic showing the decrease of percentage from 2014/2015 until 2016/2017 in the senior high schools in Surakarta. It was also supported by the average score of the students' daily assessment on the topic which was still under the Minimum Learning Exhaustiveness. Cell metabolism consists of three subchapters namely enzymes, catabolism, and anabolism. The results of interviews with some high-school students in Surakarta showed that the metabolism topic was quite dense and complicated to be studied so that they need a media that can facilitate them in understanding the topic. Furthermore, the media is also capable of stimulating the students' HOTs.

\section{RESEARCH METHODOLOGY}

This research is a Research and Development ( $R \& D$ ) conducted in one of the senior high schools in Surakarta. The population comprised of 132 twelfth-grade Science students. The random sampling technique was based on the results of the pre-test of the students' HOTs which showed a homogeneous average score in the entire population. The sample used in this research was 66 twelfth-grade Science students divided into two classes, the control class, and the experimental class or module class. The quantitative data were analyzed using two independent-samples t-test with SPSS program IBM 21. Before data analysis, prerequisite tests were performed in the form of homogeneity and normality tests on the pre-test and post-test data of the experimental and control classes.

\section{Results AND DATA ANALYSES}

\section{A. Homogeneity Test}

Table 1. Homogeneity-Test Results Test of Variance Homogeneity

\begin{tabular}{|c|c|r|r|r|r|}
\hline \multicolumn{7}{|c|}{ Test of Variance Homogeneity } \\
\hline & $\begin{array}{c}\text { Levene } \\
\text { Statistic }\end{array}$ & df1 & df2 & \multicolumn{1}{|c|}{ Sig. } \\
\hline \multirow{2}{*}{$\begin{array}{c}\text { Transfer of } \\
\text { knowledge }\end{array}$} & Based on Mean & 1,89 & 1 & 62 & 0.17 \\
\cline { 2 - 7 } & Based on Median & 1,83 & 1 & 62 & 0.18 \\
\hline
\end{tabular}

\begin{tabular}{|c|c|r|r|r|r|}
\hline & $\begin{array}{c}\text { Based on Median and } \\
\text { Adjusted df }\end{array}$ & 1,83 & 1 & 60,05 & 0.18 \\
\cline { 2 - 5 } & $\begin{array}{c}\text { Based on Trimmed } \\
\text { Mean }\end{array}$ & 1,95 & 1 & 62 & 0.17 \\
\hline
\end{tabular}

The homogeneity-test results showed a significant value of 0.174 greater than 0.05 meaning that the values of pre-test and post-test between the control and the experimental classes were the same or homogeneous. Thus, the t-test can be used to test the effectiveness of the Stim-HOTs module.

\section{B. Normality test}

Table 2. Normality-Test Results

\begin{tabular}{|l|c|r|r|r|r|r|r|}
\hline \multicolumn{9}{|c|}{ Normality Test } \\
\hline & Classes & \multicolumn{2}{|c|}{ Kolmogorov-Smirnov } & \multicolumn{3}{|c|}{ Shapiro-Wilk } \\
\hline & & Statistic & df & \multicolumn{1}{c|}{ Sig. } & Statistic & df & Sig. \\
\hline \multirow{2}{*}{$\begin{array}{l}\text { Transfer of } \\
\text { knowledge }\end{array}$} & Science 2 & 0.12 & 32 & $0.20^{*}$ & 0.95 & 32 & 0.19 \\
\cline { 2 - 9 } & Science 3 & 0.09 & 32 & $0.20^{*}$ & 0.98 & 32 & 0.84 \\
\hline
\end{tabular}

*. This is a lower bound of the true significance.

a. Lilliefors Significance Correction

The results of the normality test showed that the significant value of the control class was 0.188 and that of the module class was 0.841 . The significant values of both classes were greater than 0.05 which means that the scores of pre-test and post-test are normally distributed.

\section{C. $t$-Test}

Table 3. t-Test Results

\begin{tabular}{|c|c|c|c|c|c|}
\hline \multicolumn{6}{|c|}{ Group Statistics } \\
\hline & Classes & $\mathrm{N}$ & Mean & $\begin{array}{c}\text { Std. } \\
\text { Deviation }\end{array}$ & $\begin{array}{c}\text { Std. Error } \\
\text { Mean }\end{array}$ \\
\hline $\begin{array}{c}\text { Transfer of } \\
\text { Knowledge }\end{array}$ & Science 3 & 32 & 32.45 & 10.28 & 1.82 \\
\cline { 2 - 6 } & Science 2 & 32 & 24.76 & 12.81 & 2.26 \\
\hline
\end{tabular}

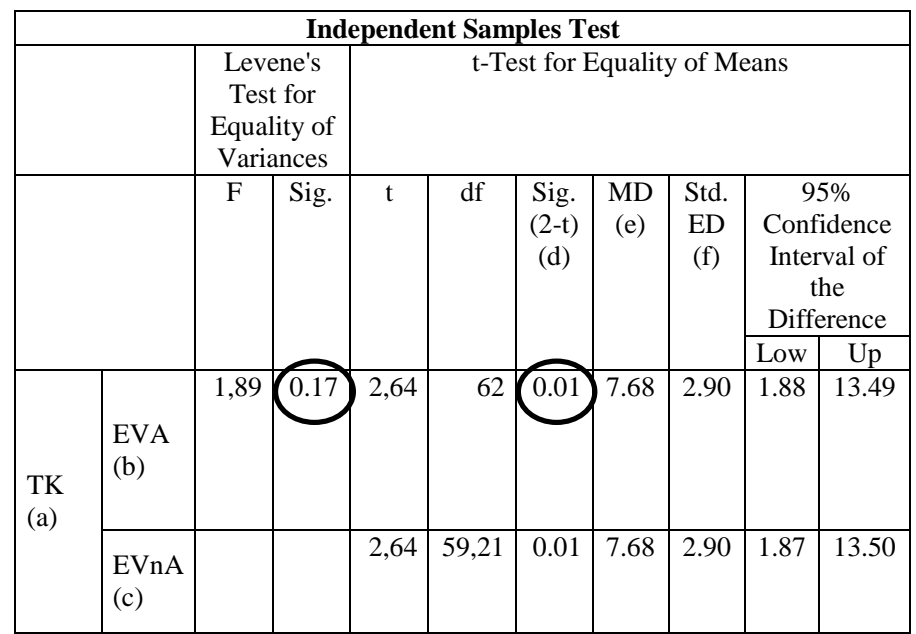

Information:

(a) TK: Transfer of knowledge

(b) EVA: Equal variances assumed

(c) EvnA: Equal variances not assumed

(d) Sig. (2-t): Sig. (2-tailed)

(e) MD: Mean Difference

(f) Std.ED: Std. Error Difference

The t-test results of testing the effectiveness of the module indicated that there was a difference of the post-test scores between the control class and the module class. The significance value of 0.174 was greater than 0.05 ; then it can be assumed that both variants are equal. The significance value ( 2 tailed) of 0.010 less than 0.05 indicated the posttest scores of the module class were better than those of the 
control class. Therefore, the Stim-HOTs module is effective for stimulating the students' HOTs.

\section{RESEARCH DISCUSSIONS}

The Stim-HOTs model that forms the basis of the metabolism module in this research is a model developed based on the study of several learning theories that form the basis of how to teach thinking skills to the students or learners. The learning theory on the which development is based on is Dewey's theory that explained that the ability of individual thinking is essentially the same in context. Furthermore, he explained that thinking is a process of something abstract to become clear. During the thinking process, there is a sequence of events, ranging from a process of investigation that encourages critical thinking to the process of solving problems and the process of conclusion by involving personal beliefs [14]. Another learning theory is Bruner's theory in which implications we often know as the spiral curriculum. The meaning of this curriculum is that basic concepts can be taught simply and complexly as the child grows. This constructivism theory gives students different stimuli according to their cognitive capabilities and experience [15].

The other constructivism theories are Piaget's and Vygotsky's theories. Piaget's theory is commonly known as building students' schemata based on their prior knowledge. According to Piaget, a child's cognition develops according to the age and stages of thinking so that the early knowledge of students needs to be considered as the foundation of the next stage of thinking [15]. Vygotsky's theory supports Piaget's theory but emphasizes the role of the social environment in the development of learning. We often call the application of his theory as the instructional scaffolding [15].

The Stim-HOTs model has syntaxes by the theories above so that the stimulation of higher-order thinking skills of the students is more focused. As described by [11], the syntaxes of this model consist of 6 stages, among others: orientation, questioning, information exploration, discussion, explanation, and reflection. Each syntax or stage of the model contained in the module provides a new learning experience for students to stimulate the students' HOTs. The framework of Stim-HOTs syntaxes is further summarized in Table 4 [11].

\begin{tabular}{|l|l|l|}
\hline \multicolumn{1}{|c|}{ Thinking skills } & \multicolumn{1}{|c|}{ Underlying theories } & \multicolumn{1}{|c|}{$\begin{array}{c}\text { Learning } \\
\text { phases/ } \\
\text { syntaxes }\end{array}$} \\
\hline Basic knowledge & $\begin{array}{l}\text { Piaget's theory of cognitive } \\
\text { development and Bloom's } \\
\text { thought about learning taxonomy }\end{array}$ & Orientation \\
\hline $\begin{array}{l}\text { Critical thinking, } \\
\text { problem-solving, } \\
\text { and creative } \\
\text { thinking }\end{array}$ & $\begin{array}{l}\text { Dewey's theory about inventive } \\
\text { thinking and Socratic-Dialogue } \\
\text { method }\end{array}$ & Questioning \\
\hline $\begin{array}{l}\text { Inquiry } \\
\text { Complex and } \\
\text { communication }\end{array}$ & $\begin{array}{l}\text { Dewey's thinking theory and } \\
\text { Bruner's inventive theory } \\
\text { theory }\end{array}$ & $\begin{array}{l}\text { Information } \\
\text { exploration }\end{array}$ \\
\hline Reasoning & Dewey's thinking theory & Discussion \\
\hline Metacognition & $\begin{array}{l}\text { Dewey's thinking theory and } \\
\text { Marzano's thought }\end{array}$ & Reflection \\
\hline
\end{tabular}

A module is one of the teaching materials that is packed intact and systematic. It can be studied by the students independently to achieve the learning objectives based on the basic competence [16-20]. The Stim-HOTs module has characteristics that match the basic competencies to be achieved and has content that trains HOTs. HOTs in question is the ability to think in the realm of C4-C6; they are analyzing, evaluating, and creating according to Bloom's taxonomy revised by Anderson \& Karthwohl.

The selection of metabolism topic, as described in the introduction, is based on the analysis of the absorptive capacity of national examination from 2014/2015 to 2016/2017 in the senior high schools in Surakarta. Furthermore, the exposure of the absorptive capacity of the national exam on metabolism topic in one of the senior high schools in Surakarta is as follows: school absorptive capacity in $2014 / 2015$ on the metabolism topic was $76.75 \%$ with the regional absorptive capacity of $67.75 \%$ and national absorptive capacity of $64,35 \%$. In $2015 / 2016$, the school absorptive capacity of the topic was $42.33 \%$ with an absorption rate of $49.64 \%$ and the national absorption rate of $47.10 \%$. In $2016 / 2017$, the school absorptive capacity of the topic was $41.46 \%$ with the regional absorptive capacity of 42.29 and the national absorptive capacity of $36.83 \%$.

Based on the results of the data analysis, the students' post-test scores indicated that the class using the module (experimental class) had higher average post-test scores than the class that did not use the module (control class). This suggests that the developed Stim-HOTs module can stimulate students' HOTs. The learning activities contained in the module consist of stages or syntaxes of Stim-HOTs that accommodate students to think in the realm of $\mathrm{C} 4, \mathrm{C} 5$, and C6. The learning environment created in the moduletreated classes affects students' psychology and provides a new learning experience for them. The students treated with the module had a sense of enthusiasm for learning and thinking process from the $\mathrm{C} 4$ stage (analyzing) to C6 (creating) which can be done well. Budsankom, et al [21] mapped out factors affecting HOTs using MASEM (MetaAnalysis Structural Equation Model) and found 4 loading factors including: (1) the factors that directly affect HOTs consisting of psychology, classroom environment, and intellectuality; (2) psychological characteristics and family characteristics directly influenced by the classroom environment; (3) classroom environment and family characteristics directly influenced by intellectuality; (4) family characteristics affecting psychology that indirectly also affect HOTs.

In the learning process, the role of the teacher is as a facilitator who directs students in the thinking process to be more focused on students' HOTs stimulation. The students who were initially passive became active during the learning process. This shows that there has been a learning revolution from teacher-centered to student-centered learning. Metabolism topic considered to be complicated and difficult to understand by the students becomes a fun material for them to learn and master. Dryden and Vos [22] in their book entitled "The Learning Revolution", explain that there are several key principles in the learning revolution, among others, the effectiveness of learning closely related to a fun learning environment, independent learning, the ability of educators to accommodate different learning styles and the optimal use of the work of the brain, and the participation of parents and family in the learning process of their children. 
HOTs stimulation in learning is necessary especially in this century, not only on a national scale but also on an international scale. The awareness of the importance of HOTs in Indonesia is contained in the National Education System Law No. 20 the Year 2003 [23] namely: the students' potentials to become critical, creative, and independent human being is growing. This means that Indonesia's national education system is aimed at providing a learning environment that enables the development of the students' potentials to acquire knowledge and higher-order thinking skills (HOTs) to be central to classroom learning. The stimulation of HOTs in classroom learning can be facilitated, one of which is by using a model-based module that contains materials and exercises that can stimulate HOTs so students can practice and study the subject matter independently. The results of this stimulation process will be more optimal if it can be done continuously.

\section{CONCLUSIONS}

HOTs are the skills that need to be mastered by the students in the $21^{\text {st }}$ century to cope with the ongoing technological changes and advancements. HOTs in classroom learning can be trained or stimulated by using learning media and models focused on HOTs stimulation. The Stim-HOTs module in this research was used as a tool to stimulate the students' HOTs, especially on metabolism topic. The results of the research data analysis showed that the students' HOTs can be well stimulated using the StimHOTs module. This can be seen from the t-test based on mean between the control class and the experimental class or the module class. The average post-test score after being treated using the Stim-HOTs module in the module class is higher than that in the control class (without the module). Furthermore, the Stim-HOTs module can be developed in other topics so that HOTs stimulation still continues in order to obtain high-school outcomes with higher-order thinking skills.

\section{ACKNOWLEDGMENT}

The researchers would like to thank the Institute of Research and Community Service of Sebelas Maret University which has provided funding support for the PNBP research under the contract No.543/UN27.21/PP/2018.

\section{REFERENCES}

[1] Gardiner, M O., Rahayu, S I., Abdullah, M A., Effendi, S., Darma, Y., Dartanto, T., Aruan, C D. (2017). Era Disrupsi. Peluang dan Tantangan Pendidikan Tinggi Indonesia. Jakarta: Akademi Ilmu Pengetahuan Indonesia.

[2] Ledward, B. C., and D. Hirata. (2011). An overview of $21^{\text {st }}$ century skills. Summary of $21^{\text {st }}$ Century Skills for Students and Teachers, by
Pacific Policy Research Center. Honolulu: Kamehameha SchoolsResearch \& Evaluation.

[3] Partnership for $21^{\text {st }}$ Century Skills (P12). (2015). Framework for $21^{\text {st }}$ Century Learning. Retrieved on January 3, 2017 from P21 Partnership for $21^{\text {st }}$ Century Skill: http://www.p21.org/ourwork/P21-framework.

[4] Miri, B., Ben-Chaim, D \& Zoller, U. (2007). Purposely teaching for the promotion of higher-order thinking skills: A case of critical thinking. Res Sci Educ 37: 353-369.

[5] Resnick, B. L. (1989). Education and learning to think. Washington. D.C: National Academic Press.

[6] Zohar, A. (2004). Higher order thinking in science classroom: Students' learning and teachers'professional development. UK: Springer-Science + Business Media B.V.

[7] Teare, B. (2005). Effective resources for able \& talented children. New York: Continuum International Publishing Group.

[8] Brookhart, S. M. (2010). Assess high order thinking skills in your classroom. Virginia: ASCD.

[9] Bloom, S. B., Engelhart, D. M., Furst, J. E., Hill, H. W., \& Krathwohl, R. D. (1956). Taxonomy of educational objectives, book I: Cognitive domain. New York: David McKay Company, Inc.

[10] Anderson, O.W. \& Krathwohl, D. R. (2001). A taxonomy for learning, teaching, and assessing: a revision of bloom's taxonomy of educational objectives. New York: Longman.

[11] Afandi \& Sajidan. (2017). Pedoman Model Stimulating Higher Order Thinking Skill (Stim-HOTs). Surakarta: UNS Press.

[12] Pratiwi, Herwim Enggar, Suwono, H, Handayani, N. (2013). Pengembangan Modul Pembelajaran Biologi Berbasis Hybrid Learning untuk Meningkatkan Kemampuan Berpikir Kritis dan Hasil Belajar Siswa Kelas XI. Malang: UM Press.

[13] Marth, Michaela \& Bogner, Franz X. (2017). Does the issue of bionic a student-centered module generate long-term knowledge? Germany: Universitatsstr.30, 95447 Bayreuth.

[14] Dewey, J. (1933). How We Think: a restatement of the relation of reflective thinking to the educative process. Boston: D.C. Heath and Company.

[15] Schunk, Dale.H. (2012). Learning Theories an Educational Perspective. Pustaka Pelajar: Yogyakarta.

[16] Daryanto. (2013). Menyusun Modul: Bahan Ajar Untuk Persiapan Guru Dalam Mengajar. Yogyakarta: Gava Media.

[17] Winkel, W.S. (2009). Psikologi Pengajaran. Jakarta: PT. Gramedia Widia Sarana Indonesia.

[18] Sudjana \& Rivai. (2007). Teknologi Pengajaran.Bandung: Sinar baru.

[19] Majid, A. (2007). Perencanaan Pembelajaran Mengembangkan Standar Kompetensi Guru. Bandung: PT Remaja Rosdakarya.

[20] Mulyasa, E. (2005). Manajemen Berbasis Sekolah. Bandung: Remaja Rosdakarya.

[21] Budsankom, P., Sawangboon, T., Damrongpanit, S., \& Chuensirimongkol, J. (2015). Factors affecting higher order thinking skills of students: a meta-analytic structural equeation modeling study. Educational Research and Reviews: 2639-2652.

[22] Dryden, G \& Vos, J. (2002). The Learning Revolution: To Change the Way the Learns. Translated into "Revolusi Cara Belajar: Belajar Akan Efektif Kalau Anda Dalam Keadaan Fun". Bandung: Penerbit Kaifa.

[23] The Law of the Republic of Indonesia No.20 Year 2003 about National Education System. Chapter 1 Article 1 Line 20 (On-line). www.inherent-dikti.net/files/sisdiknas.pdf. Retrieved on October 24, 2017. 